\title{
Factors affecting work stress in university
}

\author{
Fatwa Tentama ${ }^{1}$, Surahma Asti Mulasari ${ }^{2}$, Netty Merdiaty ${ }^{3}$ \\ ${ }^{1}$ Faculty of Psychology, Universitas Ahmad Dahlan, Indonesia \\ ${ }^{2}$ Faculty of Public Health, Universitas Ahmad Dahlan, Indonesia \\ ${ }^{3}$ Faculty of Psychology, Universitas Bhayangkara Jakarta Raya, Indonesia
}

\begin{tabular}{l} 
Article Info \\
\hline Article history: \\
Received Jun 9, 2019 \\
Revised Jul 20, 2019 \\
Accepted Aug 21, 2019 \\
\hline Keywords: \\
Employee \\
University \\
Workload \\
Work motivation \\
Work stress \\
\hline
\end{tabular}

\begin{abstract}
Workload and work motivation are factors that can affect work stress. This study aims to empirically examine the effect of workload and work motivation on work stress on employees at X University. The research participants were non-educational employees at $X$ University, have permanent employee status, and had worked for at least 1 year. The sampling technique used was simple random sampling technique. Data collection was carried out using workload scale, work motivation scale and work stress scale. Data analysis using multiple linear regression techniques. The results showed that workload and work motivation simultaneously affect work stress. Similarly, workload and work motivation independently also has a very significant influence on work stress.
\end{abstract}

Copyright @ 2019 Institute of Advanced Engineering and Science. All rights reserved.

\section{Corresponding Author:}

Fatwa Tentama,

Faculty of Psychology,

Ahmad Dahlan University,

Kapas Street No.9, Semaki, Umbulharjo, Yogyakarta.

Email: fatwa.tentama@psy.uad.ac.id

\section{INTRODUCTION}

Human resource is one of the most critical elements that organization must manage to achieve organizational goals. Organizations with skilled human resources have the strength to face competition [1]. According to Mathis and Jackson [2], human resource is the formal systems in an organization designed to achieve organizational goals effectively. Employees face various demands and work pressure to compete in achieving organizational goals. Working environment, work demand, workload, organizational rules, and even family demands, can contribute in developing work stress for employees [3].

High level of work stress could negatively impact the organization [4]. According to Fako [5], employees with high level of work stress will withdraw from the stressor by creating problems for the company such as showing performance inefficiency, wasting operational resources, and causing work constraints for other employees. Meanwhile, Luthans [6] stated that the impact of work stress could threaten and disrupt employees by causing irritability, emotional instability, non-cooperative behavior, and sleeping difficulty. Mohsan, Nawaz, and Khan [7] found that a high level of work stress will negatively impact employees and harm the organization.

According to Luthans [6], stress is the body's response that is not specific to each demand or burden. Ivancevich, Konopaske, and Matteson [8] defined stress as the interaction between an individual with his or her environment - adaptive responses connected by individual differences and psychological processes as consequences of external actions, situations or events that place excessive psychological and physical demands on someone. Stress is a condition that suppresses a person's psychological state when there are barriers that limit them pursuing an opportunity [9]. 


\section{The effect of workload on work stress}

Excessive workloads can cause tension and mental and physical fatigue, resulting in work stress [10]. According to Krantz, Berntsson, and Lundberg [11], excessive workloads can increase work stress and employee complaints about shoulder and neck pain, fatigue, headache, stomach problems, lower back pain, and sleep disorders. Similarly, Kang, Chiu, Hu, Chen, Lee, and Chang [12] found that employees with excessive workload have higher work stress and emotional reactions, such as headache, indigestion, and irritability.

Workloads are diverse demands that cover quantitative, qualitative, mental and physical tasks [13]. Haga, Shinoda, and Kokubun [14] describe workload as a level of processing capacity issued during work that reflects the power possessed by the demands of the task. A workload is defined as the total amount of work that must be done by individuals within a specified period [15]. Workload reflects the number or difficulty of one's work which includes any variable [16].

\section{The effect of work motivation on work stress}

Gallstedt [17] found that work motivation affects work stress, namely that employees with poor work motivation are more susceptible to work stress. This is because work motivation could aid employees in solving various challenges, including work stress. According to LePine, LePine, and Jackson [18], high work motivation can reduce work stress. Meanwhile, Mathis and Jackson [2] also stated that work motivation influences work stress. Similarly, Barney and Elias [19] affirmed that employees with low work motivation would easily experience work stress because in the organization some demands and responsibilities must be resolved and employees with high level of work motivation will find it easier to complete the task to avoid work stress.

According to Ivancevich [20], work motivation is an attitude and value that influence individuals to act in a goal-oriented manner. George and Jones [21] define work motivation as a psychological impulse that determines the direction of behavior, grit, and persistence or endurance of employees' work performance in the organization. Work motivation is the encouragement or enthusiasm that arises when a person works because of the external stimuli, namely receiving orders from the boss, fulfilling their needs and satisfaction, or fulfilling the responsibility assigned by the organization [22]. This study aimed to empirically examine the effect of workload and work motivation on work stress in employees at X University.

\section{RESEARCH METHOD}

\subsection{Research participant}

The participants in this study are 40 non-educative employees at X University. The selection of research participants was randomly drawn using a simple random sampling technique. The criteria of the participant in this study are as follows: 1) A non-educational employee at X University. 2) Has permanent employee status. 3) Has been working for at least one year.

\subsection{Instruments}

This study collects data using several scales. The work stress scale was arranged according to the aspects of work stress by Schultz and Schultz [23], Beehr and Newman [24] and Robbins [25], namely physiological, psychological, and behavioral aspects. We used the differential semantic scale model for the work stress scale.

The workload scale refers to three workload categories by Lysaght, et al. [26] namely the number of jobs and things that must be done, time and certain aspects of time that must be considered by workers and subjective psychological experience of workers. This workload instrument is in the form of a Likert-scale.

Work motivation was measured using work motivation scale according to Herzberg (Robbin) [25]. This scale consists of the following aspects: security, advance, type of work, co-worker, company, pay, and hours of work. This scale is also in the form of a Likert-scale.

\subsection{Instrument validity and reliability}

The results of the trial analysis of 30 subjects on the work stress scale obtained the reliability coefficient $(\alpha)$ of 0.913 with the corrected item-total correlation ranging from 0.325 to 0.820 .12 items were valid and reliable to be used in this study. The results of a trial analysis of 30 subjects on the workload scale obtained the reliability coefficient $(\alpha)$ of 0.836 with the corrected item-total correlation ranging from 0.306 to 0.557 . Valid and reliable items that could be used for research were 18 items. The results of a trial analysis of 30 subjects on the work motivation scale obtained the reliability coefficient $(\alpha)$ of 0.917 with the corrected item-total correlation moving from 0.282 to 0.824 . In total, 40 items were considered valid and reliable. 


\subsection{Data analysis}

The data analysis was conducted by using parametric statistical methods. Data analysis was performed using SPSS 17.0 for windows, through multiple regression technique, a statistical analysis technique to determine the effect of workload and work motivation on work stress.

\section{RESULTS AND DISCUSSIONS}

\subsection{Testing of assumptions}

\subsubsection{Normality test}

Based on the normality test as shown in Table 1, we found that the significance values of work stress, workload and work motivation variables were $0.854,0.211$ and 0.868 with $\mathrm{p}>0.05$, indicating that each data were normally distributed.

Tabel 1. Normality test

\begin{tabular}{cccc}
\hline Variable & K-SZ Score & Sig. & Notes \\
\hline Work Stress & 0.608 & 0.854 & Normal \\
Workload & 1.060 & 0.211 & Normal \\
Work Motivation & 0.597 & 0.868 & Normal \\
\hline
\end{tabular}

\subsubsection{Multicollinearity test}

Table 2 shows that workload and work stress have VIF values $=1.399$ (VIF<10) and tolerance 0.715 (tolerance >0.1), meaning that there is no multicollinearity between workload and work motivation.

Table 2. Multicollinearity test

\begin{tabular}{cccc}
\hline Variable & Tolerance & VIF & Notes \\
\hline Workload & 0.715 & 1.399 & No multicollinearity \\
Work motivation & 0.715 & 1.399 & No multicollinearity \\
\hline
\end{tabular}

\subsubsection{Heteroscedasticity test}

Based on Table 3 we found that workload has a significance value of 0.939 ( $p>0.05$ ) while work motivation has a significance value of $0.829(\mathrm{p}>0.05)$. In other words, there is no issue of heteroscedasticity.

Table 3. Heteroscedasticity test

\begin{tabular}{cccc}
\hline Variable & Significance & $\mathrm{P}$ & Notes \\
\hline Workload & 0.939 & $\mathrm{P}>0.05$ & No heteroscedasticity \\
Work motivation & 0.829 & $\mathrm{P}>0.05$ & No heteroscedasticity \\
\hline
\end{tabular}

\subsection{Regression Analysis}

\subsubsection{Partial analysis}

Table 4 shows that the effect of workload on work stress has value of $t=1.330$ with a significance level of $\mathrm{p}=0.008(\mathrm{p}<0.05)$, indicating that workload has a very significant affect on work stress. The magnitude of the effect of work motivation on work stress has the value of $t=2.815$ with a significance level of $p=0.02(p<0.05)$, meaning that work motivation also has a significant effect on work stress.

Table 4. Partial analysis

\begin{tabular}{ccccc}
\hline Variable & $\mathrm{t}$ & Sig & $\mathrm{P}$ & Notes \\
\hline Workload on work stress & 1.330 & 0.008 & $\mathrm{P}<0.01$ & A very significant effect \\
Work motivation on work stress & 2.815 & 0.02 & $\mathrm{P}<0.05$ & A significant effect \\
\hline
\end{tabular}

\subsection{Multiple Regression Analysis}

Table 5 indicates that workload and work motivation simultaneously has a very significant effect on work stress, indicated by a significance value of $\mathrm{p}=0.000(\mathrm{p}<0.01)$. 
Table 5. Multiple regression analysis

\begin{tabular}{cccccr}
\hline Variable & $\mathrm{R}$ & $\mathrm{F}$ & Significance & $\mathrm{p}$ & Notes \\
\hline Workload and work motivation on work stress & 0.341 & 9.578 & $\mathrm{P}=0.000$ & $\mathrm{p}<0.01$ & A very significant effect \\
\hline
\end{tabular}

These results indicate that the first hypothesis is confirmed. In other words, work stress can be predicted by workload and work motivation. Collectively, the two independent variables contribute $34.1 \%$ to work stress. The remaining $65.9 \%$ is influenced by other variables outside the scope of this study. Based on the results of the partial analysis, the second hypothesis is also accepted, indicating that workload affects the work stress of employees at X University. A high workload can result in employee work stress. According to Leslie and Lyod [27], an extremely high level of workloads will cause physical and mental fatigue and emotional reactions such as headache, and irritability. An excessive or low workload can cause work stress. The current result is in line with the results of the research by Krantz, Berntsson, and Lundberg [11]. They found that there was an effect of workload on work stress of employees.

Furthermore, our findings also confirmed the third hypothesis, meaning that work motivation has a significant positive influence on the work stress of non-educative employees at X University. This result contradicts Hsu, Chen, Yu, and Lou [28] who found that partial work motivation does not affect work stress. However, the findings in this study were supported by Wallgren and Hanse [29] who discovered that work motivation affects work stress, whereby high employee work motivation results in a decrease in their stress level and vice versa. According to George and Jones [21], the level of work stress can be predicted based on the employees' work motivation. A sense of security, cooperative coworkers, and appropriate salary will reduce the stress level of employees at work even if the employees are faced with various stacked up work.

Non-educative employees at X University are currently faced with a high level of workload. Employees have targets and deadlines that must immediately be achieved to appease various parties such as lecturers, employees, and systems run by the university. Continuous new tasks and various work conditions causes employees to face many stacked-up works. Additionally, team leaders also demand that the work is completed properly and according to the prescribed standards, causing further stress for non-educative employees. Work stress on employees is seen physiologically, psychologically and behaviorally when they work. The existence of a high level of workload can lead to increased work stress, increasing the need for a high motivation to compensate such a burden. Thus, our findings imply that high-level workload must be accompanied by high employee motivation to avoid employees from experiencing excessive work stress.

\section{CONCLUSION}

The mental health state of employees is characterized by low work stress, allowing them to be more productive at work. Based on our findings, workload and work motivation simultaneously affect work stress. Similarly, workload and work motivation independently also has a very significant influence on work stress.

\section{ACKNOWLEDGEMENTS}

The author would like to thank Research and Development Institute of Ahmad Dahlan University Yogyakarta for facilitating and funding the implementation of this research.

\section{REFERENCES}

[1] Cusway, B., "Human reseurce management: Planning analysis performance reward", London, Kogan, 2002.

[2] Mathis, RL., Jockson, HJ., "Human resource management”, South Western, College Publishing, 2010.

[3] Daft, RL., "The new era of management", Mason, South-Western Thomson, 2006.

[4] Goswami, TG., "Job stress and its effect on employee performance in banking sector", Indian Journal of Commerce \& Management Studies, vol/issue: 6(2), pp. 51-56, 2015.

[5] Fako, TT., “Occupational stress among university employees in Botswana”, European Journal of Social Sciences, vol/issue: 15(3), pp. 313-326, 2010.

[6] Luthans, F., "Organization behavior", New York, Mc Graw-Hill, 2005.

[7] Mohsan, F., Nawaz, MM., Khan, MS., "Impact of stress on job performance of employees working in Banking sector of Pakistan", Interdiciplinary Journal of Contemporary Research in Business, vol/issue: 3(2), pp. 1982-1991, 2011.

[8] Ivancevich, MJ., Konopaske, R., Matteson, TM., “Organizational behavior and management”, Baston, McGraw Hill, 2007.

[9] Robbins, SP., "Organisational behaviour”, San Diego, Prentice Hall, 2008. 
[10] Bultmann, U., Kant, IJ., Van Den Brandt, PA., Kasl, SV., "Psychosocial work characteristics as risk factors for the onset of fatigue and psychological distress: Prospective results from the Maastricht Cohort Study", Psychological Medicine, vol/issue: 32(2), pp. 333-345, 2002.

[11] Krantz, G., Berntsson, L., Lundberg, U., "Total workload, work stress and perceived symptoms in Swedish male and female white-collar employees" The European Journal of Public Health, vol/issue: 15(2), pp. 209-214, 2005.

[12] Kang, CM., Chiu, HT., Hu, YC., Chen, HL., Lee, PH., Chang, WY., "Comparisons of self-ratings on managerial competencies, research capability, time management, executive power, workload and work stress among nurse administrators", Journal of Nursing Management, vol/issue: 20(7), pp. 938-947, 2012.

[13] Cooper, CL., Dewe, PJ., O'Driscoll, MP., "Organizational stress: A review and critique of theory, research, and applications", Thousand Oaks, CA, Sage Publications, 2001

[14] Haga, S., Shinoda, H., Kokubun, M., "Effect of task difficulty and time-on-task on mental workload", Japanese Psychological Research, vol/issue: 44(3), pp. 134-143, 2002.

[15] Morris, R., MacNeela, P., Scott, A., Treacy, P., Hyde, A., "Reconsidering the conceptualization of nursing workload: Literature review", Journal of Advanced Nursing, vol/issue: 57(5), pp. 463-471, 2007.

[16] Bowling, NA., Kirkendall, C., "Workload: A review of potential causes, consequences, and interventions", New York, John Wiley \& Sons, 2012.

[17] Gällstedt, M., "Working conditions in projects: Perceptions of stress and motivation among project team members and project managers", International Journal of Project Management, vol/issue: 21(6), pp. 449-456, 2003.

[18] LePine, JA., LePine, MA., Jackson, CL., "Challenge and hindrance stress: Relationships with exhaustion, motivation to learn, and learning performance", Journal of Applied Psychology, vol/issue: 89(5), pp. 883-891, 2004.

[19] Barney, CE., Elias, SM., "Flex-time as a moderator of the job stress-work motivation relationship: A three nation investigation", Personnel Review, vol/issue: 39(4), pp. 487-502, 2010.

[20] Ivancevich, JM., "Human resource management”, New York, McGraw Hill, 2010.

[21] George, JM., Jones, GR., "Understanding and managing organizational behavior”, New Jersey, Prentice Hall, 2005.

[22] Harvey, LD., "Motivation and work behavior", New York, Accademic Press, 2006.

[23] Schultz, DP., Schultz, S. E., "Psychology and work today: An introduction to industrial and organizational psychology", New York, Macmillan Publishing Company, 2009.

[24] Beehr, TA., Newman, JE., "Job stress, employee health and organizational effectiveness: A facet analysis, model and literature review", Personnel Psychology, vol/issue: 31(4), pp. 665-669, 1978.

[25] Robbins, SP., "Organizational behaviour concept, contoversiest, applications", New Jersey: Prentice Hall. 2004.

[26] Lysaght, RJ., Hill, SG., Dick, AO., Plamondon, BD., Linton, PM., Wierwille, WW., Zaklad, AL., Bittner, Jr, AC. \& Wherry. RJ., "Operator workload: Comprehensive review and evalution of operator workload methodologies", Technical Report 851. U.S. Army Research Institutes Field Unit, USA, (1989).

[27] Leslie W., Lyod, L., "Human resource management", New York, McGraw-Hill Irwin, 2007.

[28] Hsu, HY., Chen, SH., Yu, HY., Lou, JH., "Job stress, achievement motivation and occupational burnout among male nurses", Journal of Advanced Nursing, vol/issue: 66(7), pp. 1592-1601, 2010.

[29] Wallgren, LG., Hanse, JJ., "Job characteristics, motivators and stress among information technology consultants: A structural equation modeling approach", International Journal of Industrial Ergonomics, vol/issue: 37(1), pp. 51$59,2007$. 